\title{
Methodological Approaches to DNA Authentication of Foods, Wines and Raw Materials for Their Production
}

\author{
Aram G. Galstyan ${ }^{1}$, Vladislav K. Semipyatniy ${ }^{2, *(D)}$, Irina Yu. Mikhailova ${ }^{1,2}$, Khamid Kh. Gilmanov ${ }^{1}$, \\ Alana V. Bigaeva ${ }^{1}$ and Ramil R. Vafin ${ }^{1,2} \mathbb{D}$ \\ 1 All-Russian Research Institute of the Dairy Industry, Lusinovskaya str. 35, 115093 Moscow, Russia; \\ a_galstyan@vnimi.org (A.G.G.); vniipbivp@fncps.ru (I.Y.M.); kh_gilmanov@vnimi.org (K.K.G.); \\ a_bigaeva@vnimi.org (A.V.B.); r_vafin@vnimi.org (R.R.V.) \\ 2 All-Russian Scientific Research Institute of Brewing, Beverage and Wine Industry, Rossolimo str. 7, \\ 119021 Moscow, Russia \\ * Correspondence: semipyatniy@gmail.com; Tel.: +7-(995)-901-1051
}

\section{check for}

updates

Citation: Galstyan, A.G.;

Semipyatniy, V.K.; Mikhailova, I.Y..;

Gilmanov, K.K..; Bigaeva, A.V.; Vafin,

R.R. Methodological Approaches to

DNA Authentication of Foods, Wines

and Raw Materials for Their

Production. Foods 2021, 10, 595.

https://doi.org/10.3390/foods10030595

Academic Editors:

Vassilis Dourtoglou and Salam

A. Ibrahim

Received: 30 January 2021

Accepted: 3 March 2021

Published: 11 March 2021

Publisher's Note: MDPI stays neutral with regard to jurisdictional claims in published maps and institutional affiliations.

Copyright: (C) 2021 by the authors. Licensee MDPI, Basel, Switzerland. This article is an open access article distributed under the terms and conditions of the Creative Commons Attribution (CC BY) license (https:// creativecommons.org/licenses/by/ $4.0 /)$

\begin{abstract}
DNA authentication of wines is a process of verifying their authenticity by genetic identification of the main plant component. The sample preparation of experimental and commercial wines was carried out by precipitation of wine debris by centrifugation with preliminary exposure with precipitators and co-precipitators, including developed macro- and micro-volume methods applicable to white or red wines, using polyvinylpyrrolidone as a co-precipitator. Addition of 2mercaptoethanol and proteinase $\mathrm{K}$ to the lysing solution made it possible to adapt the technology for DNA extraction from the precipitated wine debris. The additionally tested technique of DNA extraction from wine debris by dimethyl sulfoxide (DMSO) lysis had fewer stages and, consequently, a lower risk of contamination. The results of further testing of one of the designed primer pairs (UFGT-F1 and UFGT-R1) in conjunction with the tested methods of wine material sample preparation and nucleic acid extraction, showed the advantage in the given set of oligonucleotides over previously used ones in terms of sensitivity, specificity and reproducibility. The developing strategy for genetic identification of grape varieties and DNA authentication of wines produced from them based on direct sequencing of polymerase chain reaction (PCR) products is implemented by interpreting the detected polymorphic positions of variable Vitis vinifera L. UFGT gene locus with distribution and split into 13 UFGT gene-associated groups.
\end{abstract}

Keywords: Vitis vinifera L; wine; sample preparation; authentication; DNA extraction and amplification; UFGT; SNP

\section{Introduction}

The search for objective criteria for assessing the authenticity and the place of origin of food products with the possibility of traceability of the entire life cycle "from field to counter" is a strategically important task that can only be achieved by multidisciplinary science-intensive approaches [1].

The development of genomic, post-genomic and bioinformatic technologies increase the potential of molecular genetic approaches to DNA authentication of products and raw material for their production, unfolding perspectives of pilot design/elaboration in the quality management system with monitoring of counterfeit products, including wine [2].

DNA authentication of wines-a technological process of verification of their authenticity by genetic identification of the main plant component-technical varieties of grapes, molecular genetic analysis of residual nucleic acids of Vitis vinifera L., extracted also from precipitated wine debris formed at the stage of sample preparation of biomaterial under research [3].

Various methods of sample preparation of wines based on centrifugation of debris precipitation with an additional use of precipitants and co-precipitants are known in the art. 
F. Savazzini and L. Martinelli (2006) [4] performed sample preparation of commercial wines by precipitation of wine debris by centrifugation with preliminary exposure of the wine in a mixture with $\mathrm{NaCl}$ or isopropanol or sodium acetate in a freezer $\left(-20^{\circ} \mathrm{C}\right)$ for 1-2 weeks. From the listed precipitators, L. Pereira et al. (2011) [5] opted for isopropanol and a 2-week exposure at a similar temperature, and V. Catalano et al. (2016) [6] reproduced this proven method of sample preparation in their research.

J. Drábek et al. (2008) [7] performed sample preparation of commercial wines by centrifugal precipitation of wine debris with preliminary short-term exposure at room temperature of a mixture of wine with ethylenediaminetetraacetic acid (EDTA) and linear polyacrylamide, as well as supplementary addition of $\mathrm{MgCl}_{2}$ or $\mathrm{NaCl}$ in combination with isopropanol.

J. Bigliazzi et al. (2012) [8] used a combination of two precipitators-isopropanol and sodium acetate for aging commercial and experimental wines with night exposure of the resulting mixtures at $-20^{\circ} \mathrm{C}$ and further centrifugation, whereas R. Vignani et al. (2019) [2] aged the mixture in similar proportions of precipitators at $-80^{\circ} \mathrm{C}$ for 3 days.

Isci B. et al. (2014) [9] precipitated relatively large volumes (from 100 to $750 \mathrm{~mL}$ ) of stum and wine by high-speed centrifugation, or smaller volumes of the sample ( $45 \mathrm{~mL})$ mixed with $\mathrm{NaCl}$ after a week's exposure in the freezer. The applied principle of centrifugal precipitation without precipitators had a certain similarity with the previously proposed approaches described in the research works of R. Siret et al. (2000) [10] and E. GarciaBeneytez et al. (2002) [11].

The article by C. Agrimonti and N. Marmiroli (2018) [12] provides a summary of the methods of DNA extraction from precipitated wine debris with references to a number of scientific articles that also reflect the relevant sample preparation procedures.

The most common approaches to the extraction of nucleic acids from precipitated wine debris are methods based on a modification of the well-known cetyltrimethylammonium bromide (CTAB) method, which is based on cell lysis with a buffer with an active compound of CTAB, deproteinization with chloroform, and DNA precipitation with isopropanol [3].

Lysis of resuspended sediment is usually carried out by a multicomponent buffer system, which includes such reagents as EDTA - ethylenediaminetetraacetic acid, Tris$\mathrm{HCl}$ - Tris(hydroxymethyl)aminomethane hydrochloride, $\mathrm{NaCl}$ — sodium chloride, $\mathrm{CTAB}$ cetyltrimethylammonium bromide, $\mathrm{PVP}$ - polyvinylpyrrolidone, 2-mercaptoethanol) $[4,8,10]$, including proteinase $\mathrm{K}[5,6]$.

In the basic list of CTAB-modified methods for extracting nucleic acids of Vitis vinifera L. from wines can be attributed to conditionally named approaches Siret [10], Savazzini and Martinelli [4], Pereira [5] and Bigliazzi [8] in original and optimized productions [6], which have similar and distinctive features.

Along with the CTAB method, commercial nucleic acid extraction kits were also used, such as the "QIAprep Spin Miniprep Kit" (Qiagen) [8,10,13], "DNeasy Plant Mini Kit" (Qiagen) [4,11,14,15], "NucleoSpin Food" (Macherey-Nagel) [16], “QuickExtract Seed DNA Extraction Solution" (Epicentre Biotechnologies) [17].

In comparative testing of many commercial kits for DNA extraction V. Catalano et al. (2016) [6] indicated a certain effectiveness of some of them: "Dneasy Plant mini kit" (Qiagen), "High Pure polymerase chain reaction (PCR) template preparation kit" (Roche) and "Power Soil DNA isolation kit" (MO-BIO) subject to their minor modifications associated with the addition of $\alpha$-amylase and/or proteinase $K$, to improve the performance of testing systems.

Using nuclear microsatellite loci (nSSR) [18-20] and chloroplast (cpSSR) [21-23] DNA which were intended for genetic identification of grapes variety is one of the approaches to DNA authentication of wines $[1-6,8-13,17,24-26]$, a sequential procedure which is carried out with separately taken SSR-marker primer set, and not multiplex PCR.

From the variety of highly polymorphic nSSR markers, identifiable results of a number of markers are noted: VrZAG79 [5,6], VVS2, VVMD27 [4,8], and VVMD25 [8], which are 
appropriate for DNA authentication of wine with interpretation of data from fragmentary analysis of the capillary sequencer.

Less polymorphic cPSSR markers of chloroplast DNA, despite their weak discrimination ability, have greater abundance on the cell, greater resistance to exonucleases and less susceptibility to degradation due to their presence in double-membrane organelles, which is especially important when working with residual nucleic acid of Vitis vinifera extracted from wines [6].

Together with SSR markers, SNP markers have a high identification potential that are suitable for genetic identification of Vitis vinifera L. varieties and DNA authentication of wines produced from them by interpreting the results of sequencing and/or analysis of high-resolution melting curves (HRM analysis) on PCR platforms with fluorescence hybridization detection [27-31].

The purpose of the research is to create scientific and methodological approaches to DNA authentication of wine products and the main raw material for its production.

In accordance with the purpose of the research work, the following tasks were set:

- to test well-known and developed methods for sample preparation and extraction of nucleic acids of the Vitis vinifera $\mathrm{L}$. from raw grapes and wines produced from them;

- to develop a strategy for their DNA authentication by interpreting the detected polymorphic positions of variable Vitis vinifera L. UFGT gene by direct sequencing of the PCR product.

\section{Materials and Methods}

The research was conducted in the laboratory of the Interdisciplinary scientifictechnical center of food products quality control of the All-Russian Research Institute of Brewing, Non-Alcoholic and Wine Industry.

Objects of research: technical (wine) grape varieties, experimental young wines, commercial white and red monosort dry wines of protected geographical indications and protected names of places of origin.

The work involves molecular genetic research methods aimed at sample preparation and extraction of nucleic acids from research objects, amplification and sequencing of generated PCR products, as well as bioinformatic and mathematical analysis, including the development of a specialized database in the context of DNA authentication of wine products and raw material for its production.

Sample preparation of technical grape varieties was carried out by extracting 50-100 mg of grape pulp adjacent to the exocarp, with further placement of the selected sample of plant tissue in a $1.5 \mathrm{~mL}$ Eppendorf-type test tube.

Sample preparation of experimental and commercial wines was carried out by precipitation of wine debris by centrifugation with preliminary exposure with precipitators and co-precipitators. Isopropanol (I) was used as precipitators in combination with sodium acetate (II), in combination with co-precipitators-linear polyacrylamide (III) and polyvinylpyrrolidone (IV), as part of sample preparation in a $15 \mathrm{~mL}$ Falcon-type test tube. Sample preparation in a $1.5 \mathrm{~mL}$ Eppendorf-type test tube was performed in a mixture of red wine with isopropanol and polyvinylpyrrolidone $(\mathrm{V})$.

A visual diagram of the components of the tested sample preparation methods (I-IV) is shown in Table 1.

Nucleic acids were extracted from the grape pulp using a commercial “DNA-Sorb-S-M kit" (Central research Institute of Epidemiology, Russia), and from the precipitated wine debris - a modification of this kit with adding of $4 \mu \mathrm{L}$ of 2-mercaptoethanol and $100 \mu \mathrm{L}$ of proteinase $\mathrm{K}(10 \mathrm{mg} / \mathrm{mL})$ to the lysing solution. In addition, the technique of DNA extraction from wine debris by dimethyl sulfoxide (DMSO) lysis has been tested.

The stages of the tested methods for extracting nucleic acids from wine debris are shown in Table 2. 
Table 1. Elements of sample preparation stages by precipitation of wine debris by centrifugation with pre exposure with precipitators and co-precipitators.

\begin{tabular}{|c|c|c|c|c|}
\hline I & II & III & IV & $\mathbf{V}$ \\
\hline $15 \mathrm{~mL}$ Falcon-type test tube & $15 \mathrm{~mL}$ Falcon-type test tube & 15 mL Falcon-type test tube & 15 mL Falcon-type test tube & $\begin{array}{l}1.5 \mathrm{~mL} \text { Eppendorf-type } \\
\text { test tube }\end{array}$ \\
\hline $8 \mathrm{~mL}$ wine & $7 \mathrm{~mL}$ wine & $7 \mathrm{~mL}$ wine & $7 \mathrm{~mL}$ white wine & $100 \mu \mathrm{L}$ red wine \\
\hline- & - & $15 \mu \mathrm{L}$ linear polyacrylamide solution & $10 \mathrm{mg}$ PVP & $10 \mathrm{mg}$ PVP \\
\hline- & $700 \mu \mathrm{L} 3 \mathrm{M}$ sodium acetate & $700 \mu \mathrm{L} 3 \mathrm{M}$ sodium acetate & $700 \mu \mathrm{L} 3 \mathrm{M}$ sodium acetate & - \\
\hline $6 \mathrm{~mL}$ cold isopropanol & $7 \mathrm{~mL}$ cold isopropanol & $7 \mathrm{~mL}$ cold isopropanol & $7 \mathrm{~mL}$ cold isopropanol & $900 \mu \mathrm{L}$ cold isopropanol \\
\hline$-20^{\circ} \mathrm{C} 1-14$ days & $-20^{\circ} \mathrm{C} 1-3$ days & $-20^{\circ} \mathrm{C} 1-24 \mathrm{~h}$ & $-20^{\circ} \mathrm{C} 1-24 \mathrm{~h}$ & $20^{\circ} \mathrm{C} 10 \mathrm{~min}, 1-10$ days \\
\hline $3000 \mathrm{rpm}^{*} 1 \mathrm{~h}$ & $3000 \mathrm{rpm} * 1 \mathrm{~h}$ & $3000 \mathrm{rpm} * 1 \mathrm{~h}$ & $3000 \mathrm{rpm} * 1 \mathrm{~h}$ & $15000 \mathrm{rpm}^{* *} 10 \mathrm{~min}$ \\
\hline
\end{tabular}

* applied to low-speed centrifuge “CM-6M" (Elmi, Riga, Latvia). ** applied to microcentrifuge “CM-50” (Elmi, Riga, Latvia).

Table 2. Stages of proven methods of DNA extraction from precipitated wine debris.

\begin{tabular}{|c|c|}
\hline $\begin{array}{l}\text { Extraction with the "DNA-Sorb-S-M Kit" } \\
\text { in Modification }\end{array}$ & Extraction by Dimethyl Sulfoxide Lysis (DMSO) \\
\hline $\begin{array}{l}\text { Resuspension of wine debris in } 521 \mu \mathrm{L} \text { of lysing solution ( } 400 \mu \mathrm{L} \text { of } \\
\text { buffer for lysing reagent, } 17 \mu \mathrm{L} \text { of lysing reagent, } 4 \mu \mathrm{L} \text { of } \\
\text { 2-mercaptoethanol, } 100 \mu \mathrm{L} \text { of proteinase } \mathrm{K} \text { ) by tube vortexing }\end{array}$ & Resuspending of wine debris in $300 \mu \mathrm{L} 100 \%$ DMSO by tube vortexing \\
\hline$\eta$ & 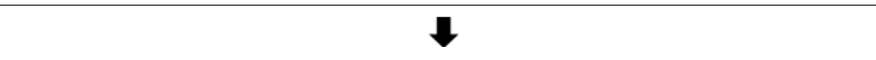 \\
\hline $\begin{array}{c}\text { Incubation of the resultant mixture at } 64^{\circ} \mathrm{C} \text { for } 60 \mathrm{~min} \text { with periodic } \\
\text { stirring on the vortex every } 10-12 \mathrm{~min}\end{array}$ & $\begin{array}{c}\text { Incubation of the resultant mixture at } 64^{\circ} \mathrm{C} \text { for } 30 \mathrm{~min} \text {. with periodic } \\
\text { stirring on the vortex every } 10 \mathrm{~min}\end{array}$ \\
\hline$\eta$ & $v$ \\
\hline $\begin{array}{l}\text { Precipitation of undissolved sample particles by centrifugation at } \\
\qquad 10,000 \times \mathrm{g} \text { for } 5 \mathrm{~min}\end{array}$ & $\begin{array}{l}\text { Precipitation of undissolved sample particles by centrifugation at } \\
\qquad 10,000 \times g \text { for } 10 \mathrm{~min}\end{array}$ \\
\hline 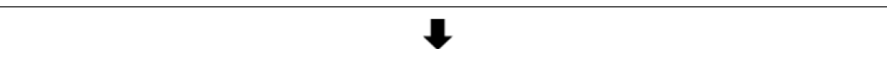 & $v$ \\
\hline $\begin{array}{c}\text { Selection of the lysate supernatant }(400-450 \mu \mathrm{L}) \text { and transfer to a test } \\
\text { tube with a sorbent }(25 \mu \mathrm{L})\end{array}$ & $\begin{array}{c}\text { Selection and transfer of the lysate supernatant }(250 \mu \mathrm{L}) \text { into a new } \\
\text { test tube }\end{array}$ \\
\hline$\eta$ & $\downarrow$ \\
\hline $\begin{array}{l}\text { Tube vortexing, exposure in a rack for } 10 \mathrm{~min} \text { with periodic stirring on } \\
\text { the vortex every } 2 \mathrm{~min}\end{array}$ & $\begin{array}{l}\text { Mixing of lysate with } 250 \mu \mathrm{L} \text { of } 4 \mathrm{M} \text { ammonium acetate and } 1 \mathrm{~mL} \text { of } \\
\text { cold isopropanol (1:1:4 ratio) }\end{array}$ \\
\hline $\boldsymbol{v}$ & $\boldsymbol{v}$ \\
\hline Centrifugation at $2000 \times g$ for $1 \mathrm{~min}$ & Exposure of the resultant mixture at $-20^{\circ} \mathrm{C}$ for $60 \mathrm{~min}$ \\
\hline 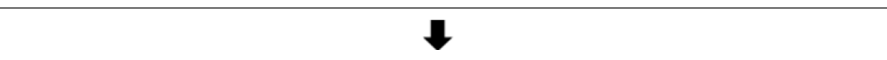 & 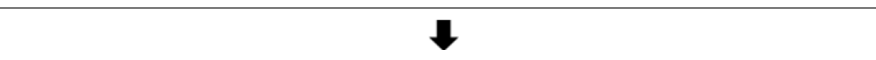 \\
\hline Removal of the supernatant & $\begin{array}{l}\text { Precipitation of the nucleoprotein complex by centrifugation at } \\
\qquad 10,000 \times g \text { for } 10 \mathrm{~min}\end{array}$ \\
\hline 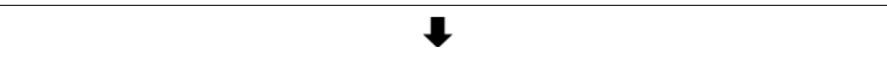 & $v$ \\
\hline $\begin{array}{c}\text { Resuspending of the sorbent in } 300 \mu \mathrm{L} \text { of washing solution } 1 \text { by } \\
\text { vortexing the test tube }\end{array}$ & Removal of the supernatant \\
\hline$\eta$ & 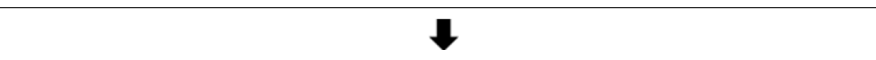 \\
\hline Centrifugation at $2000 \times g$ for $1 \mathrm{~min}$ & $\begin{array}{c}\text { Insertion of } 500 \mu \mathrm{L} \text { of cold } 70 \% \text { ethanol to the deposited } \\
\text { nucleoprotein complex }\end{array}$ \\
\hline 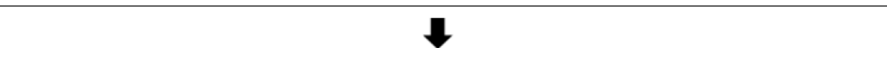 & 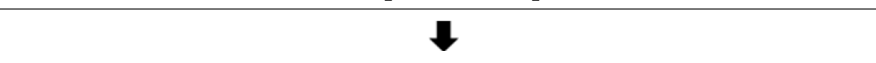 \\
\hline Removal of the supernatant & $\begin{array}{l}\text { Vortexing the test tube. Exposure in a rack for } 10 \mathrm{~min} \text { with periodic } \\
\text { stirring on the vortex every } 5 \mathrm{~min}\end{array}$ \\
\hline $\boldsymbol{t}$ & $\boldsymbol{V}$ \\
\hline $\begin{array}{l}\text { Resuspending of the sorbent in } 500 \mu \mathrm{L} \text { of the solution for washing } 2 \text { by } \\
\text { vortexing the test tube }\end{array}$ & Centrifugation at $10,000 \times g$ for $10 \mathrm{~min}$ \\
\hline $\boldsymbol{\nabla}$ & $\boldsymbol{V}$ \\
\hline
\end{tabular}


Table 2. Cont.

\begin{tabular}{|c|c|}
\hline $\begin{array}{l}\text { Extraction with the "DNA-Sorb-S-M Kit" } \\
\text { in Modification }\end{array}$ & Extraction by Dimethyl Sulfoxide Lysis (DMSO) \\
\hline Centrifugation at $7000 \times g$ for $1 \mathrm{~min}$ & Removal of the supernatant \\
\hline $\boldsymbol{v}$ & $\boldsymbol{v}$ \\
\hline Removal of the supernatant & Incubation of test tubes with open cap at $64^{\circ} \mathrm{C}$ for $5-10 \mathrm{~min}$ \\
\hline $\boldsymbol{l}$ & 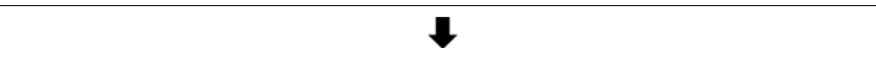 \\
\hline $\begin{array}{l}\text { Resuspending of the sorbent in } 500 \mu \mathrm{L} \text { of the solution for washing } 2 \text { by } \\
\text { vortexing the test tube }\end{array}$ & $\begin{array}{l}\text { Resuspending of the dried sediment in } 25 \mu \mathrm{L} \text { of TE buffer by incubation } \\
\text { at } 64^{\circ} \mathrm{C} \text { for } 10 \text { min with periodic stirring on the vortex every } 2 \mathrm{~min}\end{array}$ \\
\hline $\boldsymbol{V}$ & $\boldsymbol{v}$ \\
\hline Centrifugation at $7000 \times g$ for $1 \mathrm{~min}$ & Centrifugation at $10,000 \times g$ for $10 \mathrm{~min}$ \\
\hline $\boldsymbol{l}$ & 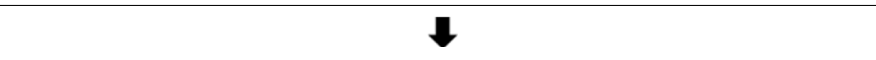 \\
\hline Incubation of test tubes with open cap at $64^{\circ} \mathrm{C}$ for $5-10 \mathrm{~min}$ & Transfer of the supernatant to a new test tube \\
\hline $\boldsymbol{\eta}$ & \\
\hline \multicolumn{2}{|l|}{$\begin{array}{c}\text { Resuspending of the sorbent in } 25 \mu \mathrm{L} \text { buffer for elution in a } \\
\text { vortexing tube }\end{array}$} \\
\hline \multicolumn{2}{|l|}{$\boldsymbol{V}$} \\
\hline \multicolumn{2}{|l|}{$\begin{array}{c}\text { Incubation of the resultant mixture at } 64^{\circ} \mathrm{C} \text { for } 5-10 \mathrm{~min} \text { with periodic } \\
\text { stirring on the vortex every } 1 \mathrm{~min}\end{array}$} \\
\hline \multicolumn{2}{|l|}{ 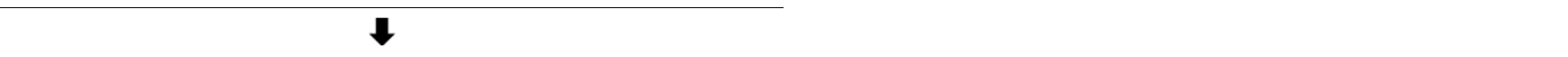 } \\
\hline \multicolumn{2}{|l|}{ Centrifugation at $10,000 \times g$ for $1 \mathrm{~min}$} \\
\hline \multicolumn{2}{|l|}{$\boldsymbol{l}$} \\
\hline \multicolumn{2}{|l|}{ Transfer of the supernatant to a new test tube } \\
\hline $\boldsymbol{v}$ & \\
\hline Transfer of the supernatant to a new test tube & \\
\hline
\end{tabular}

PCR with extracted DNA samples was performed using a commercial reagent "Encyclo Plus PCR kit" (Evrogen JSC, Moscow, Russia), which includes the necessary components of the reaction mixture (sterile water, buffer system, a mixture of deoxynucleotide (dNTP) and Encyclo polymerases), with the exception of oligonucleotide primers.

The corresponding protocols for preparing reaction mixtures for PCR with DNA samples extracted from grapes and wine debris are presented in Table 3.

Table 3. Protocols for preparing reaction mixtures for PCR with DNA samples extracted from grapes and wine debris.

\begin{tabular}{|c|c|c|c|c|c|c|}
\hline \multirow{2}{*}{ Reagents } & \multicolumn{3}{|c|}{$\begin{array}{l}\text { PCR with DNA Samples } \\
\text { Extracted from Grapes }\end{array}$} & \multicolumn{3}{|c|}{$\begin{array}{l}\text { PCR with DNA Samples } \\
\text { Extracted from Wine Debris }\end{array}$} \\
\hline & $\begin{array}{c}\text { Initial } \\
\text { Concentration }\end{array}$ & $\begin{array}{c}\text { Working } \\
\text { Concentration }\end{array}$ & $\begin{array}{c}1 \text { Test } \\
(\mu \mathrm{L})\end{array}$ & $\begin{array}{c}\text { Initial } \\
\text { Concentration }\end{array}$ & $\begin{array}{c}\text { Working } \\
\text { Concentration }\end{array}$ & $\begin{array}{c}1 \text { Test } \\
(\mu \mathrm{L})\end{array}$ \\
\hline Sterile water & - & - & 16.5 & - & - & 15 \\
\hline $5 \times$ Encyclo Red buffer & $5 \times$ & $1 \times$ & 5 & $5 \times$ & $1 \times$ & 5 \\
\hline $50 \times$ mixture dNTP & $50 \times$ & $1 \times$ & 0.5 & $50 \times$ & $2 \times$ & 1 \\
\hline Primer No. 1 & $50 \mu \mathrm{M}$ & $0.5 \mu \mathrm{M}$ & 0.25 & $50 \mu \mathrm{M}$ & $1 \mu \mathrm{M}$ & 0.5 \\
\hline Primer No. 2 & $50 \mu \mathrm{M}$ & $0.5 \mu \mathrm{M}$ & 0.25 & $50 \mu \mathrm{M}$ & $1 \mu \mathrm{M}$ & 0.5 \\
\hline $50 \times$ mixture of polymerases Encyclo & $50 \times$ & $1 \times$ & 0.5 & $50 \times$ & $2 \times$ & 1 \\
\hline DNA matrix & - & - & 2 & - & - & $2 *$ \\
\hline Final volume & - & - & 25 & - & - & 25 \\
\hline
\end{tabular}

* the volume of the DNA sample introduced into the reaction polymerase chain reaction (PCR) mixture could vary from 2 to $5 \mu \mathrm{L}$. 
Table 4 shows the list of selected primers and thermal cycling modes used for setting up PCR for genetic identification of grape varieties and DNA authentication of wines produced from them.

Table 4. Oligonucleotide primers and thermocycling modes used in PCR for the genetic identification of grape varieties and DNA authentication of wines produced from them.

\begin{tabular}{|c|c|c|c|}
\hline Gene Locus & Name and Sequence of Oligonucleotide Primers & Basic Thermal Cycling Mode* & PCR-Product \\
\hline \multirow{5}{*}{ UFGT } & $\begin{array}{l}\text { Vv1-Fwd: 5/-GCAATGTAATATCAAGTCC-3/ [30] } \\
\text { Vv1-Rev: 5/-TTTCTTTCTTTGAGCCATT-3/ [30] }\end{array}$ & $\begin{array}{c}\times 1: 95^{\circ} \mathrm{C}-300 \mathrm{~s} ; \times 40: 95^{\circ} \mathrm{C}-30 \mathrm{~s} \\
58^{\circ} \mathrm{C}-30 \mathrm{~s}, 72{ }^{\circ} \mathrm{C}-30 \mathrm{~s} ; \times 1: 72^{\circ} \mathrm{C}-300 \mathrm{~s}\end{array}$ & $705 \mathrm{bp}$ \\
\hline & $\begin{array}{l}\text { Vv3-Fwd: 5/-AGCAGAGATGGGGGTGGCTT-3/ [30] } \\
\text { Vv3-Rev: 5/-AGCAGGTAAAACCACCTGAA-3/ [30] }\end{array}$ & $\begin{array}{c}\times 1: 95^{\circ} \mathrm{C}-300 \mathrm{~s} ; \times 40: 95^{\circ} \mathrm{C}-30 \mathrm{~s}, \\
58^{\circ} \mathrm{C}-30 \mathrm{~s}, 72{ }^{\circ} \mathrm{C}-30 \mathrm{~s} ; \times 1: 72^{\circ} \mathrm{C}-300 \mathrm{~s}\end{array}$ & $119 \mathrm{bp}$ \\
\hline & $\begin{array}{l}\text { Vv3-Fwd: 5/-AGCAGAGATGGGGGTGGCTT-3/ [30] } \\
\text { UFGT-R: 5/-GCAGGTAAAACCACCTGAAACT-3/ }\end{array}$ & $\begin{array}{c}\times 1: 95^{\circ} \mathrm{C}-300 \mathrm{~s} ; \times 40: 95^{\circ} \mathrm{C}-10 \mathrm{~s} \\
62{ }^{\circ} \mathrm{C}-10 \mathrm{~s}, 72{ }^{\circ} \mathrm{C}-10 \mathrm{~s} ; \times 1: 72^{\circ} \mathrm{C}-300 \mathrm{~s}\end{array}$ & $118 \mathrm{bp}$ \\
\hline & $\begin{array}{l}\text { UFGT-F: 5/-CTTGGCTGCCGTTTTGGACT-3/ } \\
\text { UFGT-R: 5/-GCAGGTAAAACCACCTGAAACT-3/ }\end{array}$ & $\begin{array}{c}\times 1: 95^{\circ} \mathrm{C}-300 \mathrm{~s} ; \times 40: 95^{\circ} \mathrm{C}-10 \mathrm{~s} \\
62{ }^{\circ} \mathrm{C}-10 \mathrm{~s}, 72{ }^{\circ} \mathrm{C}-10 \mathrm{~s} ; \times 1: 72^{\circ} \mathrm{C}-300 \mathrm{~s}\end{array}$ & $101 \mathrm{bp}$ \\
\hline & $\begin{array}{l}\text { UFGT-F1: 5/-CTTGGCTGCCGTTTTGGA-3/ } \\
\text { UFGT-R1: 5/-AGGTAAAACCACCTGAAACT-3/ }\end{array}$ & $\begin{array}{c}\times 1: 95^{\circ} \mathrm{C}-300 \mathrm{~s} ; \times 40: 95^{\circ} \mathrm{C}-10 \mathrm{~s} \\
58^{\circ} \mathrm{C}-10 \mathrm{~s}, 72{ }^{\circ} \mathrm{C}-10 \mathrm{~s} ; \times 1: 72^{\circ} \mathrm{C}-300 \mathrm{~s}\end{array}$ & $99 \mathrm{bp}$ \\
\hline \multirow{2}{*}{ F3H1 } & $\begin{array}{l}\text { F3H_H1fwd: 5/-AGAGAAAGAAGGCGACGT-3/ [31] } \\
\text { F3H_H1rev: 5/-GATGGCTGGAAACGATGA-3/ [31] }\end{array}$ & $\begin{array}{c}\times 1: 95^{\circ} \mathrm{C}-300 \mathrm{~s} ; \times 40: 95^{\circ} \mathrm{C}-30 \mathrm{~s} \\
58^{\circ} \mathrm{C}-30 \mathrm{~s}, 72{ }^{\circ} \mathrm{C}-30 \mathrm{~s} ; \times 1: 72^{\circ} \mathrm{C}-300 \mathrm{~s}\end{array}$ & $375 \mathrm{bp}$ \\
\hline & $\begin{array}{l}\text { F3H_H2fwd: 5/-CTGTTGAAGGAGCTTTCG-3/ [31] } \\
\text { F3H_H2rev: 5/-GGCTTGGACTCTAACTTG-3/ [31] }\end{array}$ & $\begin{array}{c}\times 1: 95^{\circ} \mathrm{C}-300 \mathrm{~s} ; \times 40: 95^{\circ} \mathrm{C}-30 \mathrm{~s} \\
58^{\circ} \mathrm{C}-30 \mathrm{~s}, 72^{\circ} \mathrm{C}-30 \mathrm{~s} ; \times 1: 72^{\circ} \mathrm{C}-300 \mathrm{~s}\end{array}$ & $532 \mathrm{bp}$ \\
\hline
\end{tabular}

* applied to thermal cycler "Tertsik" (DNA-technology, Russia).

Electrophoretic detection of amplified PCR products was performed in $2.5 \%$ agarose gel on a tris-acetate-EDTA (TAE) buffer stained with ethidium bromide, followed by DNA visualization in a UV transilluminator (Vilber Lourmat, Collégien, France) and recording the result on a digital camera.

Amplicons of the analyzed UFGT gene locus generated by the UFGT-F1 and UFGT-R1 oligonucleotides (and further used as sequence primers) were sequenced on the "ABI PRISM 3100 genetic analyzer" (Applied Biosystems, Foster City, CA, USA), followed by their alignment in Basic Local Alignment Search Tool (BLAST) with the corresponding partial nucleotide sequences of Vitis vinifera L.

\section{Results}

At the first stage of molecular genetic studies, two technical grape varieties of Chardonnay and Cabernet Sauvignon were sampled by extracting grape pulp, as well as sample preparation of experimental young wines produced from them by precipitation of wine debris by centrifugation with preliminary exposure with isopropanol (method I, Table 1) during one day in the freezer.

The sample prepared material was then subjected to the procedure of extraction of nucleic acids by a commercial "DNA-sorb-S-M kit" (without modification), followed by the use of extracted DNA samples in PCR.

The electrophoretic picture of the first results of PCR amplification of the Vitis vinifera L. UFGT and F3H gene loci initiated with well-known primer sets is shown in Figure 1.

The results of preliminary studies indicated that the selected conditions for sample preparation, DNA extraction, and PCR were applicable for amplification of the analyzed gene locus directly to the raw material, but not to the wine material produced from it.

Thus, PCR of DNA samples extracted from the pulp of Chardonnay and Cabernet Sauvignon grape varieties produced a specific amplification of $705 \mathrm{bp}$ initiated with primers Vv1-Fwd and Vv1-Rev [30]; 375 bp with background non-specificity (F3H_H1fwd and F3H_H1rev [31]); 119 bp (Vv3-Fwd and Vv3-Rev [30]); 532 bp (F3H_H2fwd and F3H_H2rev [31]), respectively. At the same time, specific amplification products were not developed in PCR of DNA samples extracted from the precipitated wine debris (Figure 1). 


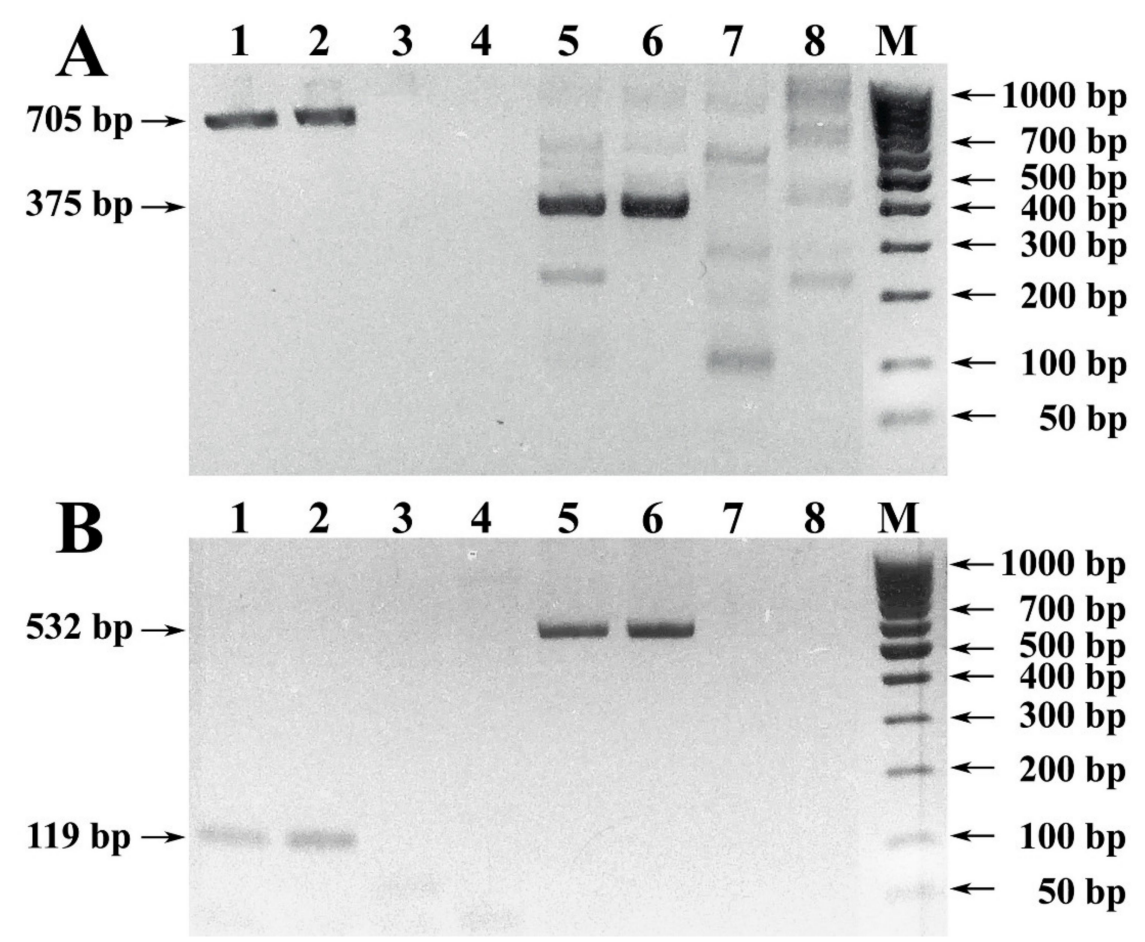

Figure 1. Electrophoregram of results of PCR amplification of the Vitis vinifera L. UFGT and F3H gene loci. Legend: (A1-4) Amplified with primers Vv1-Fwd and Vv1-Rev PCR samples of DNA extracted from grape pulp and precipitated wine debris: (A1) grape pulp of Chardonnay; (A2) grape pulp of Cabernet Sauvignon; (A3) precipitated wine debris of Chardonnay; (A4) precipitated wine debris of Cabernet Sauvignon. (A5-8) Amplified with primers F3H_H1fwd and F3H_H1rev PCR samples of DNA extracted from grape pulp and precipitated wine debris: (A5) grape pulp of Chardonnay; (A6) grape pulp of Cabernet Sauvignon; (A7) precipitated wine debris of Chardonnay; (A8) precipitated wine debris of Cabernet Sauvignon. (B1-4) Amplified with primers Vv3-Fwd and Vv3-Rev PCR samples of DNA extracted from grape pulp and precipitated wine debris: (B1) grape pulp of Chardonnay; (B2) grape pulp of Cabernet Sauvignon; (B3) precipitated wine debris of Chardonnay; (B4) precipitated wine debris of Cabernet Sauvignon. (B5-8) Amplified with primers F3H_H2fwd and F3H_H2rev PCR samples of DNA extracted from grape pulp and precipitated wine debris: (B5) grape pulp of Chardonnay; (B6) grape pulp of Cabernet Sauvignon; (B7) precipitated wine debris of Chardonnay; (B8) precipitated wine debris of Cabernet Sauvignon. (M) DNA size markers $100 \mathrm{bp}+50 \mathrm{bp}$ (SibEnzyme).

Further experiments with testing other methods of sample preparation of wine material (methods II-V, Table 1) and extraction of nucleic acids with a "DNA-Sorb-S-M kit" in modification with addition of 2-mercaptoethanol and proteinase $\mathrm{K}$ to the lysing solution, did not lead to satisfactory PCR results with the sets of primers described above.

Therefore, further studies were aimed at testing two designed sets of primers that initiate amplification of a specific PCR product with a length of $101 \mathrm{bp}$ (UFGT-F and UFGTR) and 99 bp (UFGT-F1 and UFGT-R1), respectively (Table 4). A schematic view of the sequences of the analyzed gene flanked by primers is shown in Figure 2.

\begin{tabular}{|c|c|c|c|}
\hline СTTGGCTGCCGTTTTGGA & UFGT-R1 & AGTTTCAGGTGGTTTTACCT & $99 \mathrm{bp}$ \\
\hline$\overline{\text { CTTGGCTGCCGTTTTGGACT }}$ & UFGT-R & AGTTTCAGGTGGTTTTACCTGC & $101 \mathrm{bp}$ \\
\hline Vv3-Fwd AGCAGAGATGGGGGTGGCTT & UFGT-R & AGTTTCAGGTGGTTTTACCTGC & $118 \mathrm{bp}$ \\
\hline Vv3-Fwd AGCAGAGATGGGGGTGGCTT & Vv3-Rev & TTCAGGTGGTTTTACCTGCT & $119 \mathrm{bp}$ \\
\hline
\end{tabular}

Figure 2. Partial nucleotide sequences of the UFGT gene flanked by different sets of primers. 
The results of comparative testing of the designed pair of UFGT-F and UFGT-R primers with the well-known prototype (Vv3-Fwd and Vv3-Rev) are shown in Figure 3.

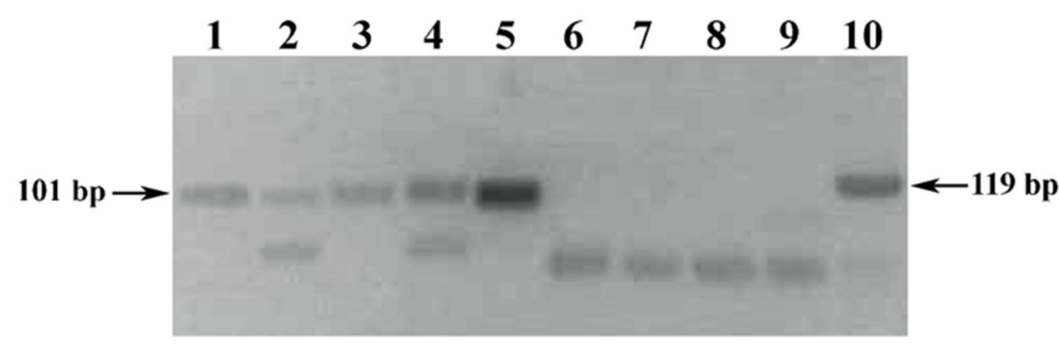

Figure 3. Electrophoregram of the results of PCR amplification of the Vitis vinifera L. UFGT gene locus. Legend: (1-4) PCR samples of DNA amplified with UFGT-F and UFGT-R primers, extracted from precipitated wine debris: (1-2) a 3-day exposure of wine material with isopropanol: (1) Chardonnay; (2) Cabernet Sauvignon. (3-4) a 7-day exposure of wine material with isopropanol: (3) Chardonnay; (4) Cabernet Sauvignon. (5) Positive control sample. (6-9) PCR samples of DNA amplified with Vv3Fwd and Vv3-Rev primers, extracted from precipitated wine debris: (6-7) a 3-day exposure of wine material with isopropanol: (6) Chardonnay; (7) Cabernet Sauvignon. (8-9) a 7-day exposure of wine material with isopropanol: (8) Chardonnay; (9) Cabernet Sauvignon. (10) Positive control sample.

The obtained results of oligonucleotides testing showed a higher sensitivity of the designed set of UFGT-F and UFGT-R primers in comparison with the prototype, which is visually confirmed by the presence (Figure 3, tracks 1-4) and the absence (Figure 3, tracks 6-9) of the amplification signal in the analyzed PCR samples. At the same time, the amplification signal of a positive control DNA sample extracted from the pulp of Chardonnay grape was stronger in PCR with the UFGT-F and UFGT-R primers (Figure 3, track 5) than with the Vv3-Fwd and Vv3-Rev primers (Figure 3, track 10), which may serve as an additional justification for the sensitivity statement.

It should be noted that the combination of well-known and designed primers resulted in a positive signal of amplification of PCR samples of the analyzed DNA samples extracted from the deposited debris of white wine material rather than red ones in the Vv3-Fwd and UFGT-R pair (Figure 4).

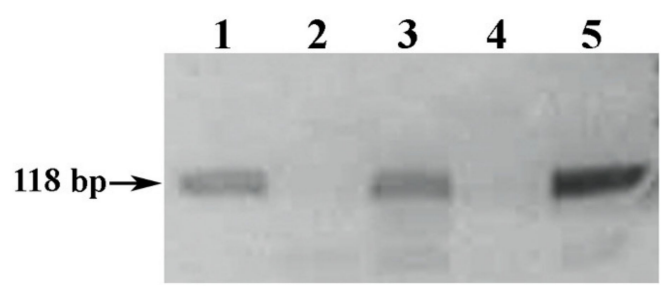

Figure 4. Electrophoregram of the result of PCR amplification of the Vitis vinifera L. UFGT gene locus with VV3-Fwd and UFGT-R primers. Legend: (1-4) PCR samples of DNA samples amplified with primers Vv3-Fwd and UFGT-R extracted from the deposited wine material debris: (1-2) a 1-h exposure of wine material mixed with isopropanol, sodium acetate and linear polyacrylamide Bioron: (1) Chardonnay; (2) Cabernet Sauvignon. (3-4) 1-h exposure of wine material mixed with isopropanol, sodium acetate and linear polyacrylamide Satellite Red: (3) Chardonnay; (4) Cabernet Sauvignon. (5) Positive control sample.

Suspensions of linear polyacrylamide from different manufacturers used in the sample preparation method III (Table 1) did not differ significantly in the efficiency of DNA coprecipitation in a mixture with isopropanol and sodium acetate, except that Satellite Red nucleic acid co-precipitator produced by Evrogen JSC, Moscow, Russia provides easy visualization of the resulting sediment, which may be relevant when working with small volumes of precipitated white wine material and wines. 
The results of further testing of another designed pair of UFGT-F1 and UFGT-R1 primers in conjunction with the tested methods of wine material sample preparation and DNA extraction showed the advantage of these oligonucleotides over previously used ones in terms of sensitivity, specificity and reproducibility.

Micro-volume rapid method for sample preparation of red wine material (method $\mathrm{V}$, Table 1) and further DNA extraction by lysis of the precipitated debris with DMSO (Table 2) also led to satisfactory PCR results with UFGT-F1 and UFGT-R1 primers initiating amplification of a specific PCR product with a length of 99 bp (tracks 1-3, Figure 5).

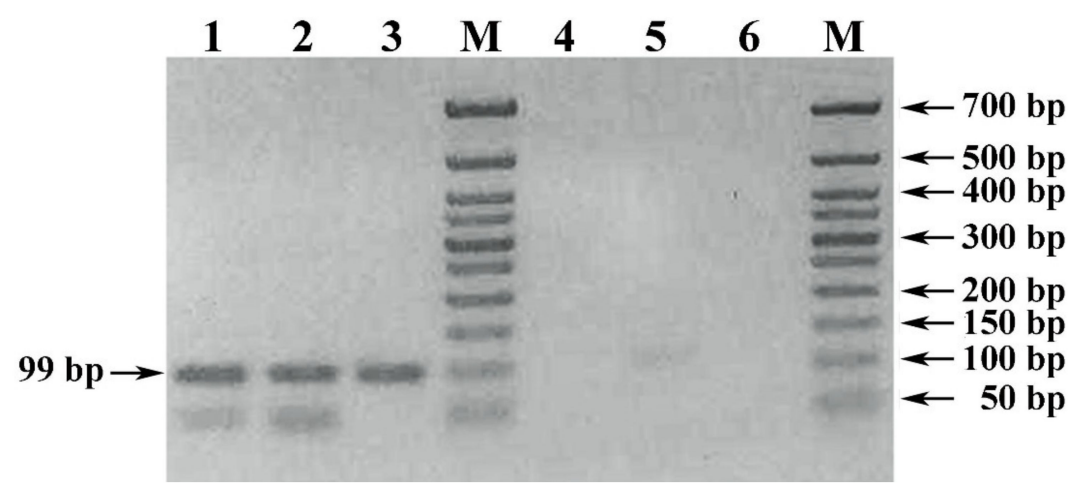

Figure 5. Electrophoregram of results of PCR amplification of the Vitis vinifera L. UFGT gene locus with UFGT-F1 and UFGT-R1 primers. Legend: (1-3) PCR of a DNA sample extracted by lysis with DMSO of the precipitated debris of young Cabernet Sauvignon wine, prepared by a 10 min exposure of the wine material mixed with PVP and isopropanol. (4-6) PCR of a DNA sample extracted by lysis with DMSO of the precipitated debris of young Cabernet Sauvignon wine, sampled by a 10 min exposure of the wine material mixed with PVP. M) DNA size markers 50+ bp (Evrogen JSC, Moscow, Russia).

However, another proven rapid method of sample preparation of experimental young red wine with a 10 min exposure of $1 \mathrm{~mL}$ of wine material mixed with $1 \% \mathrm{PVP}$ at room temperature, followed by precipitation of wine debris by centrifugation at maximum speed of the microcentrifuge for 10 min, was ineffective (tracks 4-6, Figure 5).

It should be noted that the reproducibility of PCR with DNA samples extracted from experimental young wines was higher compared to samples of nucleic acids extracted from commercial wines (Figure 6).

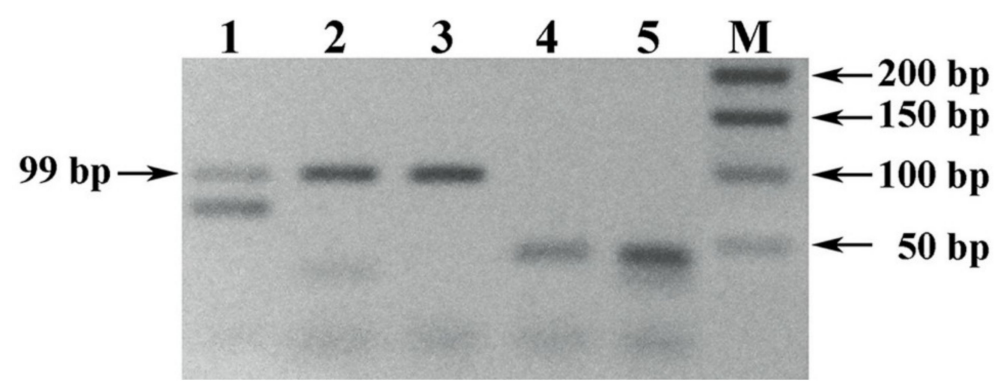

Figure 6. Electrophoregram of the result of PCR amplification of the Vitis vinifera L. UFGT gene locus with UFGT-F1 and UFGT-R1 primers for reproducibility of the reaction. Legend: (1-2) PCR of a DNA sample extracted with "DNA-sorb-S-M kit": from the precipitated debris of white wine Visigodo Sauvignon blanc, sampled with a 1-day exposure in a mixture with PVP, sodium acetate and isopropanol. (3-4) PCR of a DNA sample extracted with "DNA-sorb-S-M kit" from the precipitated red wine debris Lagar De Robla (Mencia), sampled by a 10-min exposure in a mixture with PVP and isopropanol. (5) Negative control sample. M) DNA size markers 50+ bp (Evrogen JSC, Moscow, Russia. 
As seen in Figure 6, along with the specific PCR product in one of the replications, a nonspecific shorter fragment (track 1) was also amplified, or no reaction took place at all (track 4), in case with duplicate DNA samples of the grapes Sauvignon blanc and Mencia extracted from the precipitated debris of the Visigodo and Lagar De Robla wines, respectively (Figure 6).

The negative effect of cold stabilization on the studied nucleic acid extracted from the precipitated wine debris, samples prepared from wine stored for a day in the refrigerator after uncorking the bottle, was also revealed (Figure 7).

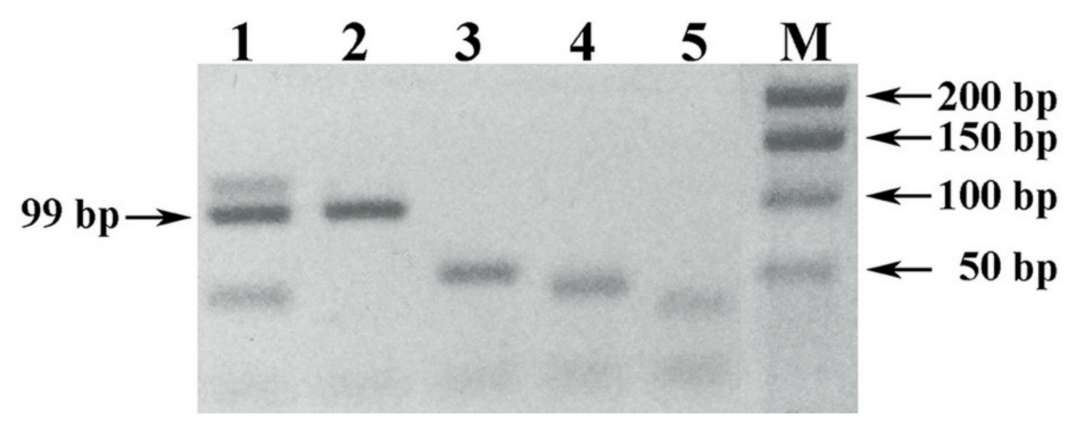

Figure 7. Electrophoregram of the result of PCR amplification of the Vitis vinifera L. UFGT gene locus with UFGT-F1 and UFGT-R1 primers for the negative effect of cold stabilization on the DNA under research. Legend: (1-2) PCR of a DNA sample extracted with "DNA-sorb-S-M kit" from the precipitated red wine debris Lagar De Robla (Mencia), sampled by a 10-min exposure in a mixture with PVP and isopropanol immediately after uncorking the bottle. (3-4) PCR of a DNA sample extracted with "DNA-sorb-S-M kit" from the precipitated red wine debris Lagar De Robla (Mencia), sampled by a 10-min exposure in a mixture with PVP and isopropanol on the next day after uncorking the bottle and storing it in the refrigerator. (M) DNA size markers 50+ bp (Evrogen JSC, Moscow, Russia).

It should be noted that the negative effect of cold stabilization on the analyzed nucleic acid, expressed in a weak amplification signal of a specific PCR product or its complete absence, was fully extended to commercial wines.

There was also poor storage in the freezer of extracted DNA samples of Vitis vinifera L. from the precipitated debris of commercial wines, which led to unsatisfactory results of PCR amplification of the analyzed UFGT gene locus. At the same time, the reproducibility of PCR with freshly extracted DNA samples that were not stored in the freezer, but were used immediately in the amplification reaction, increased.

The next stage of molecular genetic research was the sequencing of the nucleotide sequences of the UFGT gene locus amplified with UFGT-F1 and UFGT-R1 primers of PCR products of DNA samples extracted from the pulp of grape and precipitated wine debris.

UFGT-F1 and UFGT-R1 primers initiate the development of a specific PCR product with a length of 99-100 bp with localization in the flanked region (404-503 nt) of 5 polymorphic positions, including 1 indel (INDEL-insertion/deletion) and 4 positions of single nucleotide substitutions (SNPs-Single Nucleotide Polymorphisms), interpreted by sequencing during grape variety identification and DNA authentication of wines produced from them.

The result of alignment of reference nucleotide sequences of the Vitis vinifera L. UFGT gene locus flanked with the UFGT-F1 and UFGT-R1 primers with INDEL and SNPs is shown in Figure 8.

Good examples of detection of INDEL (424 nt) and SNPs (425, 459 and $483 \mathrm{nt})$ polymorphic positions of the Vitis vinifera L. UFGT gene locus performed by capillary Sanger sequencing method is shown in Figure 9.

Grouping and splitting of grape varieties by the profile of the analyzed polymorphic positions of the UFGT gene locus is one of the ways to identify them and DNA-authenticate the wines produced from them. 


\begin{tabular}{|c|c|c|c|c|c|c|}
\hline & & & & 44 & \multicolumn{2}{|l|}{4} \\
\hline & & & & 22 & 4 & \\
\hline \# & \multicolumn{3}{|c|}{ Local Primer UFGT-F1 } & 45 & 2 & \\
\hline$\overline{01}$ & $\overline{404 n t}$ & CTTGGCTGCC & $\overline{\text { GTTTTGGACT }}$ & & ААСТСАСТСТ & CCACCCATGT \\
\hline 02 & $404 \mathrm{nt}$ & CTTGGCTGCC & GTTTTGGACT & -GCAGGGCCT & ААСТСАСТСТ & CCACCCATGT \\
\hline 03 & $404 \mathrm{nt}$ & СTTGGCTGCC & GTTTTGGACT & -GCAGGGCCT & ААСТСАСТСТ & CCACCCATGT \\
\hline 04 & $404 \mathrm{nt}$ & CTTGGCTGCC & GTTTTGGACT & -GCAGGGCCT & ААСТСАСТСТ & CCACCCATGT \\
\hline 05 & $404 \mathrm{nt}$ & CTTGGCTGCC & GTTTTGGACT & -KCAGGGCCT & АACTCACTCT & CCACCCATGT \\
\hline 06 & $404 \mathrm{nt}$ & СTTGGCTGCC & GTTTTGGACT & \multirow{2}{*}{$\begin{array}{l}\text {-KCAGGGCCT } \\
\text { - GCAGGGCCT }\end{array}$} & \multirow{2}{*}{$\begin{array}{l}\text { ААСТСАСТСТ } \\
\text { ААСТСАСТСТ }\end{array}$} & CCACCCATGT \\
\hline 07 & $404 \mathrm{nt}$ & СTTGGCTGCC & GTTTTGGACT & & & CCACCCATGT \\
\hline 08 & $404 \mathrm{nt}$ & CTTGGCTGCC & GTTTTGGACT & $\begin{array}{l}\text {-GCAGGGCCT } \\
\text {-GCAGGGCCT }\end{array}$ & $\begin{array}{l}\text { AАCTCACTCT } \\
\text { AACTCACTMT }\end{array}$ & CCACCCATGT \\
\hline 09 & $404 \mathrm{nt}$ & СTTGGCTGCC & GTTTTGGACT & TGCAGGGCCT & ААСТСАСТСТ & CCACCCATGT \\
\hline 10 & $404 \mathrm{nt}$ & СTTGGCTGCC & GTTTTGGACT & TGCAGGGCCT & ААСТСАСТСТ & CCACCCATGT \\
\hline 11 & $404 \mathrm{nt}$ & СTTGGCTGCC & GTTTTGGACT & -GCAGGGCCT & ААСТСАСТСТ & CCACCCATGT \\
\hline 12 & $404 \mathrm{nt}$ & CTTGGCTGCC & GTTTTGGACT & -GCAGGGCCT & ААСТСАСТMT & CCACCCATGT \\
\hline 13 & $404 n t$ & $\begin{array}{c}\text { CTTGGCTGCC } \\
\mathbf{4}\end{array}$ & GTTTTGGACT & $\begin{array}{r}-\mathbf{K C A G G G C C T} \\
\mathbf{4}\end{array}$ & ААСТСАСТСТ & CCACCCATGT \\
\hline & & 5 & & 8 & & \\
\hline \# & Local & 9 & & 3 & Prir & ner UFGT-R1 \\
\hline$\overline{01}$ & $\overline{454 n t}$ & TTACACTGAT & GAAATCAGAG & AAAAGATTGG & $\overline{\text { AGTTTCAGGT }}$ & GGTTTTACCT \\
\hline 02 & $454 \mathrm{nt}$ & TTACACTGAT & GAAATCAGAG & AAAAGATTGS & AGTTTCAGGT & GGTTTTACCT \\
\hline 03 & $454 \mathrm{nt}$ & TTACATTGAT & GAAATCAGAG & AAAAGATTGG & AGTTTCAGGT & GGTTTTACCT \\
\hline 04 & $454 \mathrm{nt}$ & TTACAYTGAT & GAAATCAGAG & AAAAGATTGG & AGTTTCAGGT & GGTTTTACCT \\
\hline 05 & $454 \mathrm{nt}$ & TTACACTGAT & GAAATCAGAG & AAAAGATTGC & AGTTTCAGGT & GGTTTTACCT \\
\hline 06 & $454 \mathrm{nt}$ & TTACACTGAT & GAAATCAGAG & AAAAGATTGS & AGTTTCAGGT & GGTTTTACCT \\
\hline 07 & $454 \mathrm{nt}$ & TTACAYTGAT & GAAATCAGAG & AAAAGATTGS & AGTTTCAGGT & GGTTTTACCT \\
\hline 08 & $454 \mathrm{nt}$ & TTACAYTGAT & GAAATCAGAG & AAAAGATTGG & AGTTTCAGGT & GGTTTTACCT \\
\hline 09 & $454 \mathrm{nt}$ & TTACAYTGAT & GAAATCAGAG & AAAAGATTGS & AGTTTCAGGT & GGTTTTACCT \\
\hline 10 & $454 \mathrm{nt}$ & TTACATTGAT & GAAATCAGAG & AAAAGATTGS & AGTTTCAGGT & GGTTTTACCT \\
\hline 11 & $454 \mathrm{nt}$ & TTACACTGAT & GAAATCAGAG & AAAAGATTGC & AGTTTCAGGT & GGTTTTACCT \\
\hline 12 & $454 n t$ & TTACACTGAT & GAAATCAGAG & AAAAGATTGG & AGTTTCAGGT & GGTTTTACCT \\
\hline 13 & $454 n t$ & TTACAYTGAT & GAAATCAGAG & AAAAGATTGS & AGTTTCAGGT & GGTTTTACCT \\
\hline \# & PCR-pr & coduct Grape & evine cultiv & GenBank & $\mathrm{k} \mathrm{A} / \mathrm{N}$ & \\
\hline 01 & $99 \mathrm{bp}$ & Chard & donnay & JF52248 & & \\
\hline 02 & $99 \mathrm{bp}$ & Rabig & gato & JF52242 & & \\
\hline 03 & $99 \mathrm{bp}$ & Ferna & ao Pires & JF52240 & & \\
\hline 04 & $99 \mathrm{bp}$ & Tinto & o Cao & JF52251 & & \\
\hline 05 & $99 \mathrm{bp}$ & Merlo & & JF52245 & & \\
\hline 06 & $99 \mathrm{bp}$ & Touri & iga Franca & JF52251 & & \\
\hline 07 & 99 bp & Freis & & JF52249 & & \\
\hline 08 & $99 \mathrm{bp}$ & Pedro & o Ximenez & JF52240 & & \\
\hline 09 & $100 \mathrm{bp}$ & Caber & rnet Sauvign & & & \\
\hline 10 & $100 \mathrm{bp}$ & Sousa & & & & \\
\hline 11 & $99 \mathrm{bp}$ & Canno & onao & JF52252 & & \\
\hline 12 & $99 \mathrm{bp}$ & Parda & & JF52244 & & \\
\hline 13 & $99 \mathrm{bp}$ & Rondi & inella & JF52250 & & \\
\hline
\end{tabular}

Figure 8. Alignment of reference nucleotide sequences of the Vitis vinifera L. UFGT gene locus flanked with UFGT-F1 and UFGT-R1 primers. \# index number.

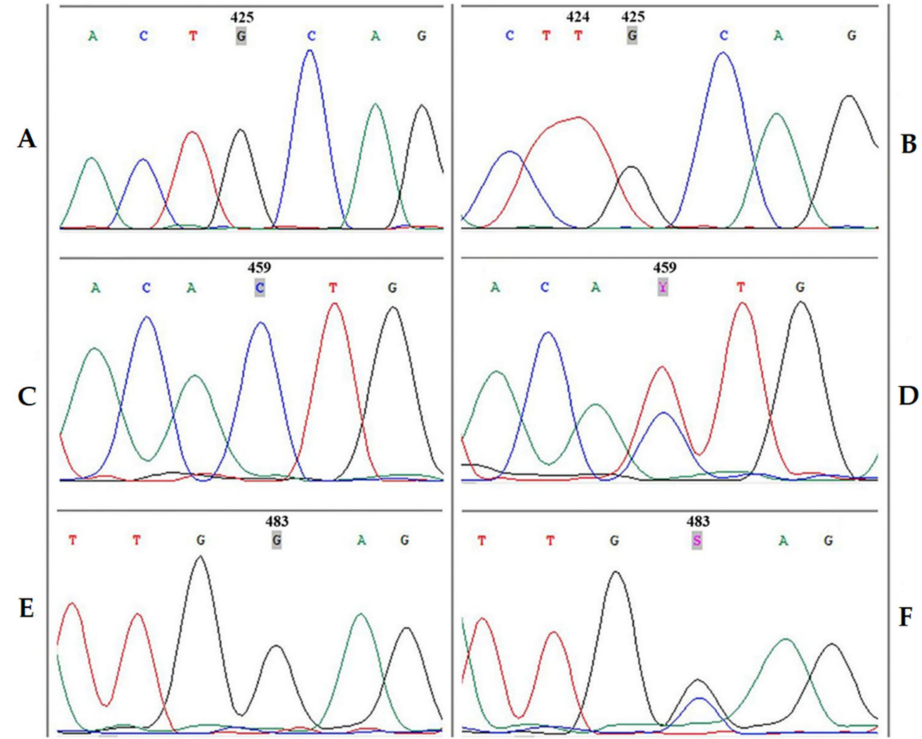

Figure 9. Detection of polymorphic positions (424/425/459/483) of the Vitis vinifera L. UFGT gene locus by capillary Sanger sequencing method. Legend: (A) position $425(\mathrm{G})$; (B) position $424(\mathrm{~T})$ and $425(\mathrm{G})$; (C) position 459 (C); (D) position 459 (Y); (E) position $483(\mathrm{G})$; (F) position $483(\mathrm{~S})$. 
Bioinformatic analysis of open source data allowed us to distribute technical grape varieties with their split into 13 UFGT gene-associated groups (Tables 5 and 6).

Table 5. Distribution of technical grape varieties according to the profile of polymorphic positions of the Vitis vinifera L. UFGT gene locus.

\begin{tabular}{|c|c|c|c|c|c|c|c|}
\hline & \multirow{2}{*}{$\#$} & \multirow{2}{*}{ Technical Grape Varieties } & \multicolumn{5}{|c|}{ Polymorphic Positions (INDEL/SNPs) } \\
\hline & & & $424 *$ & 425 & 442 & 459 & 483 \\
\hline \multirow{4}{*}{1} & \multirow{2}{*}{$\mathrm{B}^{*}$} & Chardonnay & \multirow{4}{*}{-} & \multirow{4}{*}{ G } & \multirow{4}{*}{$\mathrm{C}$} & \multirow{4}{*}{$\mathrm{C}$} & \multirow{4}{*}{ G } \\
\hline & & Gouveio & & & & & \\
\hline & \multirow{2}{*}{$N^{*}$} & Touriga Brasileira & & & & & \\
\hline & & Donzelinho Tinto & & & & & \\
\hline \multirow{4}{*}{2} & \multirow{2}{*}{ B } & Codega do Larinho & \multirow{4}{*}{-} & \multirow{4}{*}{ G } & \multirow{4}{*}{$\mathrm{C}$} & \multirow{4}{*}{$\mathrm{C}$} & \multirow{4}{*}{$S$} \\
\hline & & Rabigato & & & & & \\
\hline & \multirow{2}{*}{$\mathrm{N}$} & Tinta Amarela & & & & & \\
\hline & & Alicante Bouschet & & & & & \\
\hline \multirow{4}{*}{3} & \multirow{2}{*}{ B } & Fernao Pires & \multirow{4}{*}{-} & \multirow{4}{*}{ G } & \multirow{4}{*}{$\mathrm{C}$} & \multirow{4}{*}{$\mathrm{T}$} & \\
\hline & & Malvasia Fina & & & & & \\
\hline & & Tinta Roriz & & & & & $\mathrm{G}$ \\
\hline & $\mathrm{N}$ & Agostana Nera & & & & & \\
\hline & & Moscatel Galego & & & & & \\
\hline & B & Bianca & & C & $C$ & & \\
\hline 4 & I & Tinto Cão & 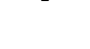 & $G$ & $c$ & $Y$ & $G$ \\
\hline & $\mathrm{N}$ & Pinot Noir & & & & & \\
\hline & B & $\begin{array}{c}\text { Trebbiano } \\
\text { RomagnoloVermentino }\end{array}$ & & & & & \\
\hline 5 & & Merlot & - & K & $\mathrm{C}$ & C & C \\
\hline & $\mathrm{N}$ & Tinta Barroca & & & & & \\
\hline 6 & B & Touriga Franca & - & - & - & - & - \\
\hline 0 & $\mathrm{~N}$ & Touriga Nacional & - & K & C & C & $S$ \\
\hline & B & Viosinho & & & & & \\
\hline 7 & $\mathrm{~N}$ & Freisa & - & $\mathrm{G}$ & $C$ & $Y$ & 5 \\
\hline 0 & B & Pedro Ximenez & & $C$ & S & Y & $C$ \\
\hline 8 & $\mathrm{~N}$ & Rufete & 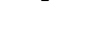 & G & $\mathrm{M}$ & $Y$ & G \\
\hline & B & - & $\mathrm{T}$ & C & C & Y & $C$ \\
\hline 9 & $\mathrm{~N}$ & Cabernet Sauvignon & 1 & $G$ & $c$ & $Y$ & 3 \\
\hline & B & - & & & & & \\
\hline 10 & $\mathrm{~N}$ & Souzão & $\mathrm{T}$ & G & $C$ & $\mathrm{~T}$ & $S$ \\
\hline & B & - & & & & & \\
\hline 11 & $N$ & Cannonao & - & G & C & C & $\mathrm{C}$ \\
\hline & N & Nero d'Avola & & & & & \\
\hline & & Parda & & & & & \\
\hline 12 & B & Blanca Cayetana & - & G & M & $\mathrm{C}$ & G \\
\hline & $\mathrm{N}$ & - & & & & & \\
\hline & B & - & & & & & \\
\hline 13 & & Rondinella & - & K & C & Y & $S$ \\
\hline & $\mathrm{N}$ & Raboso Piave & & & & & \\
\hline
\end{tabular}

* $\mathrm{B}$-blanc (white color of grape berry), $\mathrm{N}$ —noir (black color of grape berry), INDEL (424 nt). \# index number of UFGT gene-associated groups. 
Table 6. Distribution of technical grape varieties according to UFGT gene-associated groups.

\begin{tabular}{|c|c|c|}
\hline & \# & GenBank A/N (Technical Grape Varieties, Country) \\
\hline \multirow{2}{*}{1} & B & $\begin{array}{c}\text { JF522533 (Perla, Italy), JF522518 (Malvasia del Chianti, Italy), JF522500 (Robolla, Greece), JF522495 (Matilde, Italy), } \\
\text { JF522483 (Chardonnay, Italy), JF522431 (Feteasca Alba, Romania), JF522413 (Sultanina, Greece), JF522412 (Verduzzo } \\
\text { Friulano, Italy), JF522411 (Prosecco Balbi, Italy), JF522406 (Ribolla, Italy) }\end{array}$ \\
\hline & $\mathrm{N}$ & $\begin{array}{l}\text { KY293689 (Yaghuty, Iran), KY305474 (Sirch, Iran), KY305473 (Shiraz, Iran), JF522524 (Dolcetto, Italy), JF522512 } \\
\text { (Tintoria, Italy), JF522505 Bastardo, Portugal), JF522484 (Franconia, Italy), JF522470 (Carignan, Italy), JF522440 } \\
\text { (Colorino, Italy), JF522386 (Monastrel, Spain), JF522380 (Croatina, Italy) }\end{array}$ \\
\hline \multirow{2}{*}{2} & B & JF522420 (Rabigato, Portugal) \\
\hline & $\mathrm{N}$ & JF522514 (Tinta Francisca, Portugal), JF522429 (Feteasca Neagra, Romania), JF522417 (Pignola, Italy) \\
\hline \multirow[b]{2}{*}{3} & B & $\begin{array}{l}\text { KJ495698 (Trebbiano Toscano, Italy), KJ495697 (Grechetto, Italy), KJ495695 (Pecorino, Italy), JF522535 (Albarino, } \\
\text { Spain), JF522517 (Malvasia Istriana, Italy), JF522501 (Incrocio Manzoni Bianco, Italy), JF522493 (Riesling Italico, } \\
\text { Italy), JF522432 (Greco, Italy), JF522426 (Fiano, Italy), JF522401 (Vittoria, Italy), JF522385 (Xarello, Spain), JF522388 } \\
\text { (Assyrtiko, Greece), JF522459 (Sauvignon Blanc, Italy), JF522408 (Fernao Pires, Portugal) }\end{array}$ \\
\hline & $\mathrm{N}$ & $\begin{array}{l}\text { KJ495696 (Sangiovese VCR4, Italy), JF522510 (Sangiovese cR10, Italy), JF522506 (Agostana Nera, Italy), JF522486 } \\
\text { (Malbech, Italy), JF522472 (Aglianico, Italy), JF522455 (Marzemina Cenerenta, Italy), JF522456 (Marzemina Nera, } \\
\text { Italy), JF522454 (Pattaresca, Italy), JF522453 (Refosco dal Peduncolo Rosso, Italy), JF522446 (Ciliegiolo, Italy), } \\
\text { JF522436 (Teroldego, Italy), JF522427 (Petit Verdot, Italy), JF522415 (Primitivo di Gioia, Italy), JF522399 (Moscato di } \\
\text { Amburgo, Italy), JF522397 (Castelao, Portugal), JF522400 (Mencia, Italy) }\end{array}$ \\
\hline \multirow[b]{2}{*}{4} & B & $\begin{array}{c}\text { JF522528 (Bianca, Italy), JF522527 (Picolit, Italy), JF522507 (Gatta, Italy), JF522502 (Riesling Renano, Italy), JF522496 } \\
\text { (Mustoasa de Maderat, Romania), JF522491 (Pinot Blanc, Italy), JF522475 (Malvasia Fina, Portugal), JF522466 (Tocai, } \\
\text { Italy), JF522461 (Albana, Italy), JF522457 (Marzemina Bianca, Italy), JF522438 (Regina, Italy), JF522435 (Grechetto, } \\
\text { Italy), JF522424 (Feteasca Regala, Romania), JF522422 (Moscato Bianco, Italy), JF522423 (Moscato Giallo, Italy), } \\
\text { JF522410 (Parellada, Spain), JF522402 (Italia, Italy) }\end{array}$ \\
\hline & $\mathrm{N}$ & $\begin{array}{c}\text { JF522519 (Tinto Cão, Portugal), JF522511 (Gruaja, Italy), JF522489 (Pinot Noir, Italy), JF522488 (Marzemina Nera } \\
\text { Bastarda, Italy), JF522485 (Xinomavro, Greece), JF522409 (Malvasia Nera, Italy), JF522474 (Alfrocheiro, Portugal), } \\
\text { JF522447 (Canaiolo Nero, Italy), JF522468 (Raboso Piave, Italy), JF522469 (Raboso Veronese, Italy), JF522441 } \\
\text { (Agiorgitiko, Greece), JF522434 (Corbinona, Italy), JF522433 (Corbinella, Italy), JF522428 (Bovale Sardo, Italy), } \\
\text { JF522425 (Lambrusco Maestri, Italy), JF522418 (Moschomavro, Greece), JF522407 (Graciano, Spain), JF522398 } \\
\text { (Cardinal, Italy) }\end{array}$ \\
\hline \multirow[b]{2}{*}{5} & B & JF522508 (Trebbiano Romagnolo, Italy), JF522499 (Vermentino, Italy) \\
\hline & $\mathrm{N}$ & $\begin{array}{c}\text { JF522378 (Tinta Barroca, Portugal), JF522462 (Piedirosso, Italy), JF522450 (Merlot, Italy), JF522391 } \\
\text { (Malbo Gentile, Italy) }\end{array}$ \\
\hline \multirow[b]{2}{*}{6} & B & - \\
\hline & $\mathrm{N}$ & $\begin{array}{l}\text { JF522525 (Corvina, Italy), JF522516 (Touriga Franca, Portugal), JF522448 (Touriga Nacional, Portugal), JF522464 } \\
\text { (Carmenere, Italy) }\end{array}$ \\
\hline \multirow{2}{*}{7} & B & - \\
\hline & $\mathrm{N}$ & JF522497 (Freisa, Italy) \\
\hline \multirow{2}{*}{8} & B & JF522405 (Pedro Ximenez, Spain) \\
\hline & $\mathrm{N}$ & - \\
\hline \multirow{2}{*}{11 * } & B & - \\
\hline & $\mathrm{N}$ & JF522522 (Cannonao, Spain), JF522515 (Tocai Rosso, Italy), JF522442 (Nero d’Avola, Italy) \\
\hline \multirow{2}{*}{12} & B & JF522443 (Parda, Spain); JF522444 (Blanca Cayetana, Spain); JF522377 (Antao Vaz, Italy) \\
\hline & $\mathrm{N}$ & - \\
\hline \multirow[b]{2}{*}{13} & B & - \\
\hline & $\mathrm{N}$ & $\begin{array}{l}\text { JF522509 (Rondinella, Italy), JF522430 (Cabernet Franc, Italy), JF522476 (Raboso Piave, Italy), JF522477 (Raboso } \\
\text { Veronese, Italy), JF522445 (Negrara Veronese, Italy), JF522471 (Nebbiolo, Italy), JF522384 (Cabernet Sauvignon, Italy) }\end{array}$ \\
\hline
\end{tabular}

* 9 and 10 has no GenBank database representation. \# index number of UFGT gene-associated groups.

At the same time, if Table 5 provides only generalized information on a limited number of technical grape varieties of conditionally reference status with additional division by 
color of mature berry, then Table 6 provides already detailed information on distributed varieties in 13 UFGT gene-associated groups, indicating their names and countries of growth, as well as the unique identifier of the deposited nucleotide sequence (GenBank A/N).

The distribution of the studied grape varieties growing in Russia by UFGT geneassociated groups was as follows:

1B-Rkatsiteli (Derbent Brandy Factory), Rkatsiteli (Derbent Wine Factory, the southern part of Derbent), Riesling (Sparkling Wine Derbent Factory, the southern part of Derbent), Chardonnay (TWC), Chardonnay (Sommelier), Pervenets Magaracha (Phanagoria); $1 \mathrm{~N}$-Levokumsky steady (Kizlyar district, the northern part); 2B-Chinuri Gramotenko (Yalta); 2N-Malbec Gramotenko (Yalta); 4B-Muscat White (Mirny); 4N—Bastardo Gramotenko (Yalta), Yalta Vasilievsky Gramotenko (Yalta); 9N—Cabernet Sauvignon (Mirny), Cabernet Franc (Phanagoria), Cabernet Franc (Sommelier).

Sequenced PCR products of DNA samples extracted from the deposited debris of the experimental wine material had a profile of the analyzed polymorphic positions of the UFGT gene locus identical to the raw grape material used in their production.

However, the results of sequencing of PCR products of DNA samples extracted from the deposited debris of commercial wines did not always correspond to the varietyauthentic profile, which could be caused by external and internal factors.

\section{Discussion}

Sample preparation of the biomaterial under research is the starting point, the quality of which depends on the effectiveness of the next stage-extraction of nucleic acids.

Sample preparation of technical grape varieties by extracting and transferring of a small volume of pulp to an Eppendorf-type test tube is the optimal procedure for selecting biomaterial from the raw material under study, which does not require advanced tools.

Tested methods of sample preparation of experimental and commercial wines, based on their exposure to precipitators and co-precipitators with subsequent precipitation of wine debris by centrifugation, differ in elements of components (Table 1).

If the sample preparation method I involves the use of isopropanol as the only precipitator, then in method II isopropanol is used in combination with another precipitatorsodium acetate, and in other methods this combination of precipitators works in combination with such co-precipitators as linear polyacrylamide (III) and polyvinylpyrrolidone (IV). At the same time, if the four listed methods of sample preparation (I-IV) are focused on manipulations in a $15 \mathrm{~mL}$ Falcon-type test tube with exposure in the freezer, then in method $\mathrm{V}$ all procedures are performed in a $1.5 \mathrm{~mL}$ Eppendorf-type test tube with further exposure of the resulting mixture at room temperature.

Vector of positive dynamics of the specified exposure time intervals for each method (Table 1) was oriented towards increasing the aging time of mainly commercial wines mixed with precipitators and co-precipitators.

It should be noted that our method of sample preparation I is similar to the method described by L. Pereira et al. (2011) [5], and the method of sample preparation II-J. Bigliazzi et al. (2012) [8], with minor changes adapted to the instrumental characteristics of the equipment in use.

Sample preparation method III, which significantly reduces the exposure time due to the use of linear polyacrylamide mixed with isopropanol and sodium acetate, had a serious drawback associated with the time-consuming procedure of resuspending the precipitated wine debris in a $15 \mathrm{~mL}$ Falcon-type test tube even before the transfer of the homogenate to a $1.5 \mathrm{~mL}$ Eppendorf-type test tube. The given method had a certain similarity to the method described by J. Drabek et al. (2008) [7] regarding the use of linear polyacrylamide and isopropanol.

Later, two methods of sample preparation using polyvinylpyrrolidone as a co-precipitator were proposed: macro-volume method IV, intended for white wines, and micro-volume method $\mathrm{V}$, intended for red wines. 
The minimum exposure time of the micro-volume rapid method for sample preparation of red wine material is $10 \mathrm{~min}$. At the same time, small aliquots $(100 \mu \mathrm{L})$ of samples of the wine under study mixed with isopropanol $(900 \mu \mathrm{L})$ and PVP $(10 \mathrm{mg})$ can be stored at room temperature for up to 10 days, followed by centrifugation of test tubes. This approach is an alternative to storing in the freezer the test-tube wine from an uncorked bottle [10].

Micro-volume methods for sample preparation of red stum by high-speed centrifugation of an Eppendorf-type test tube with $1.5 \mathrm{~mL}$ of the test sample are known in the art $[4,11,12]$. Whereas in this research, the possibility of sample preparation from $100 \mu \mathrm{L}$ of red wine material using a precipitator (isopropanol) and a co-precipitator (PVP) is shown.

Nucleic acid extraction following the sample preparation tested with the commercial "DNA-sorb-S-M kit" showed the effectiveness of its use in the DNA extraction from the pulp of grape.

According to the instructions of "DNA-Sorb-S-M kit", it is designed for DNA extraction from biological material from animals (tissue material) and food, biological additives, animal feed or plant raw material for subsequent research by polymerase chain reaction (PCR).

The principle of the extraction method is that the test sample is treated with a lysing solution with proteinase $\mathrm{K}$, resulting in destruction of cell membranes, release of nucleic acids and cellular components. The dissolved nucleic acids bind to the sorbent particles, while other components of the lysed test material remain in the solution and are removed during deposition of sorbent by centrifugation and further washing of the sorbent. When buffer for elution is added to the sorbent, nucleic acids transitions from the surface of the silica into a solution, which is separated from the sorbent particles by centrifugation. As a result of the mentioned procedure, a highly purified nucleic acids preparation is obtained, free from amplification reaction inhibitors, which ensures high analytical sensitivity of the PCR study.

It should be noted that the composition of the lysis buffer reagent kit includes guanidine chloride and Triton X-100; the composition of the lysing reagent is proteinase $\mathrm{K}$; the solution for washing 1 is guanidine thiocyanate and Triton X-100; the solution for washing 2 is isopropanol; the universal sorbent included in the kit is fine silicon dioxide ( $\mathrm{SiO} 2)$, and the buffer for elution B is a standard TE buffer for DNA dilution.

Modification of this kit by adding additional 2-mercaptoethanol and proteinase $\mathrm{K}$ to the lysing solution made it possible to adapt the technology for extraction from precipitated wine debris (Table 2), which to a certain extent overlaps with the recommendations of $\mathrm{V}$. Catalano et al. (2016) [6], aimed at improving the performance of commercial testing systems.

J. Drabek et al. (2008) [7], in comparative testing of the commercial "DNAzol kit" (Invitrogen), which is a guanidine thiocyanate extraction method, showed its insignificant effectiveness over the CTAB method. Thiocyanate is present in the washing solution in the guanidine kit used by us, while another chaotropic agent (guanidine chloride) is part of the buffer for the lysing reagent.

Additionally, the proven technique of DNA extraction from wine debris by dimethyl sulfoxide (DMSO) lysis, which has fewer stages and, consequently, a lower risk of contamination, is an effective method with the prospect of its further optimization and adaptation in relation to systems for manual and automatic extraction of nucleic acids. (Table 2). The basic principle of the adapted nucleic acid extraction technique with minor modifications is borrowed from the previously published work of E. M. del Campo et al. (2010) [32].

PCR testing performed by commercial "Encyclo Plus PCR kit" (Evrogen JSC, Moscow, Russia) after the nucleic acid extraction showed the effectiveness of its use in standard protocols for preparing reaction mixtures in relation to DNA samples under research extracted from grape pulp (Table 3).

According to the technical characteristics of the used commercial kit, it is intended, including, amplification of complex mixtures of nucleic acids and low copy DNA matrices. 
Protocols for preparing reaction mixtures for PCR with DNA samples extracted from the precipitated wine debris differed by a two-fold increase in a number of components (dNTP mixture, Encyclo polymerase mixture, primers) in comparison with standard protocols intended for PCR with nucleic acid samples extracted from grapes raw material (Table 3).

At the same time, if the DNA extracted from grape pulp was successfully amplified in all tested PCR protocols, including with sets of well-known primers [30,31], then the amplification of DNA extracted from the precipitated wine debris was mainly achieved only with designed primers that initiate the development of the small-sized UFGT gene locus (from $99 \mathrm{bp}$ to $118 \mathrm{bp}$ ).

The inability to amplify a longer PCR product is due to significant fragmentation of the residual DNA extracted from wine debris [6]. The effectiveness of PCR drops sharply due to the fact that the DNA is fragmented to such an extent that the average size of the fragments is less than the length of the amplified gene locus.

Also, one of the reasons that did not allow us to develop a PCR product with a length of 119 bp (Figure 3, tracks 6-9) with the well-known primers Vv3-Fwd and Vv3-Rev [30] with a melting temperature difference of more than $5{ }^{\circ} \mathrm{C}$ is the relatively low DNA yield of the extraction methods used compared to Pereira method [5], which is characterized by a relatively high yield of nucleic acids extracted from the precipitated wine debris.

By combining the well-known (Vv3-Fwd) [30] and designed (UFGT-R) primers with an acceptable melting temperature difference, it became possible to obtain a positive amplification signal (118 bp) for PCR of analyzed DNA samples extracted from the precipitated white wine debris (tracks 1 and 3, Figure 4), and with two designed sets of primers UFGTF + UFGT-R and UFGT-F1 + UFGT-R1 we were able to increase reaction sensitivity to the ability to amplify PCR products from DNA samples, including those extracted from red wine material.

At the same time, the reproducibility of PCR with DNA samples extracted from commercial wines was significantly lower compared to DNA samples extracted from experimental young wines, and the negative effect of cold stabilization on the analyzed nucleic acid often led to unsatisfactory results, which is consistent with the results of other researchers [6].

It should be taken into account that the extracted DNA of Vitis vinifera L. from wine has the status of a residual nucleic acid, as its concentration is significantly reduced during the multi-stage wine production process, including decanting, cleaning, filtration and other processing methods. In addition, grape DNA is degraded by DNase microbiota of wine during the fermentation process. The yield of extracted nucleic acid also decreases as the wine ages. Thus, the amount of DNA of Vitis vinifera L. extracted from wines with final alcoholic fermentation is significantly reduced or is practically absent, depending on the timing of testing the finished product $[6,17]$.

In this research work the strategy of genetic identification of grape varieties and DNA authentication of wines produced from them based on direct sequencing of PCR products was implemented through the interpretation of the detected polymorphic positions of the variable UFGT gene locus of Vitis vinifera L., flanked by UFGT-F1 and UFGT-R1 primers, including those used as sequencing ones.

To "read" nucleotide sequencing from the direct primer UFGT-F1 allows to detect SNPs at positions $459 \mathrm{nt}$ and $483 \mathrm{nt}$, while from the reverse primer UFGT-R1-INDEL $424 \mathrm{nt}$ and SNPs 425 and $442 \mathrm{nt}$ of the analyzed gene locus.

Good examples of detection of polymorphic positions by capillary Sanger sequencing indicate a possible interpretation of the data obtained in the identification key (Figure 9).

The presented result of alignment of the reference nucleotide sequences of the Vitis vinifera L. UFGT gene locus flanked with UFGT425-F1 and UFGT483-R1 primers with INDEL and SNPs (Figure 8) was generated based on the results of bioinformatic analysis of open source data, which allowed to distribute technical grape varieties with their splitting into 13 UFGT gene-associated groups with additional division by the color of mature berry (Tables 5 and 6). 
It should be noted that the nucleotide sequences of UFGT gene-associated groups \#09 (Cabernet Sauvignon variety) and \#10 (Souzão variety) are not deposited in GenBank NCBI are only published in a scientific article [29]. At the same time, the associated group \#13 includes the nucleotide sequence of the UFGT gene locus of the Cabernet Sauvignon (JF522384) variety deposited in GenBank NCBI, including Cabernet Franc (JF522430).

It is worth mentioning that in this research the nucleotide sequences of the UFGT gene locus of the varieties Cabernet Sauvignon and Cabernet Franc growing on the territory of the Russian Federation corresponded to the associated group \#09, and not \#13. However, it should be noted that the detection of INDEL $424 \mathrm{nt}$ is somewhat difficult, which can be misinterpreted when reading the results of Sanger sequencing on a genetic analyzer.

Sequenced PCR products of DNA samples extracted from grape raw material and experimental wines produced from them generally had an identical profile of the analyzed polymorphic positions of the Vitis vinifera L.UFGT gene locus, while the results of sequencing of commercial wines sometimes did not correspond to the variety-authentic profile due to a number of factors, one of which was the loss of one of the alleles of the heterozygous genotype gene during amplification, which ultimately led to incorrect interpretation of the data.

\section{Conclusions}

The proposed strategy of DNA authentication by interpreting the detected polymorphic positions of the variable UFGT gene locus of Vitis vinifera L. by direct sequencing of PCR product is carried out in a complex of selected conditions for sample preparation, DNA extraction, and PCR for amplification of the corresponding gene loci. Taking into account the potential and limitations of tested methods, a number of proposed techniques expanding the arsenal of methodological tools, increased the rapidity of sample preparation of wine materials and wines (with co-precipitator PVP) and extraction of residual grapevine nucleic acids (with DMSO), enhanced the sensitivity, specificity and reproducibility of PCR (with primers UFGT-F1 and UFGT-R1), as well as provided identification of the UFGT gene-associated groups by sequencing. In general, the analysis of well-known and developed methodological approaches to DNA authentication of wine products and raw material for its production, including those tested in this research, indicates the need for further research to improve the methods of sample preparation and nucleic acids extraction, amplification and sequencing of generated PCR products, with the involvement of other molecular genetic methods to improve the accuracy of diagnostics. At the same time, the practical significance of the conducted and planned research is aimed at implementing developments in the management control system of raw material quality and products based on developed standards for the wine industry.

Author Contributions: Conceptualization, R.R.V. and A.G.G.; methodology, R.R.V., V.K.S. and K.K.G.; validation, I.Y.M. and A.V.B.; formal analysis, K.K.G.; investigation, V.K.S.; data curation, I.Y.M. and A.V.B.; writing — original draft preparation, I.Y.M. and A.V.B.; writing-review and editing, V.K.S.; visualization, K.K.G.; supervision, R.R.V.; project administration, A.G.G. All authors have read and agreed to the published version of the manuscript.

Funding: This research received no external funding.

Institutional Review Board Statement: Not applicable.

Informed Consent Statement: Not applicable.

Data Availability Statement: Data is contained within the article.

Conflicts of Interest: The authors declare no conflict of interest. 


\section{References}

1. Pereira, L.; Gomes, S.; Barrias, S.; Gomes, E.P.; Baleiras-Couto, M.; Fernandes, J.R.; Martins-Lopes, P. From the Field to the Bottle-An Integrated Strategy for Wine Authenticity. Beverages 2018, 4, 71. [CrossRef]

2. Vignani, R.; Liò, P.; Scali, M. How to integrate wet lab and bioinformatics procedures for wine DNA admixture analysis and compositional profiling: Case studies and perspectives. PLoS ONE 2019, 14, e0211962. [CrossRef]

3. Oganesyants, L.; Vafin, R.; Galstyan, A.; Semipyatniy, V.; Khurshudyan, S.; Ryabova, A. Prospects for DNA authentication in wine production monitoring. Food Raw Mater. 2018, 6, 438-448. [CrossRef]

4. Savazzini, F.; Martinelli, L. DNA analysis in wines: Development of methods for enhanced extraction and real-time polymerase chain reaction quantification. Anal. Chim. Acta 2006, 563, 274-282. [CrossRef]

5. Pereira, L.; Guedes-Pinto, H.; Martins-Lopes, P. An Enhanced Method for Vitis vinifera L. DNA Extraction from Wines. Am. J. Enol. Vitic. 2011, 62, 547-552. [CrossRef]

6. Catalano, V.; Moreno-Sanz, P.; Lorenzi, S.; Grando, M.S. Experimental Review of DNA-Based Methods for Wine Traceability and Development of a Single-Nucleotide Polymorphism (SNP) Genotyping Assay for Quantitative Varietal Authentication. J. Agric. Food Chem. 2016, 64, 6969-6984. [CrossRef] [PubMed]

7. Drábek, J.; Stávek, J.; Jalůvková, M.; Jurček, T.; Frébort, I. Quantification of DNA during winemaking by fluorimetry and Vitis vinifera L.-specific quantitative PCR. Eur. Food Res. Technol. 2008, 226, 491-497. [CrossRef]

8. Bigliazzi, J.; Scali, M.; Paolucci, E.; Cresti, M.; Vignani, R. DNA Extracted with Optimized Protocols Can Be Genotyped to Reconstruct the Varietal Composition of Monovarietal Wines. Am. J. Enol. Vitic. 2012, 63, 568-573. [CrossRef]

9. Işçi, B.; Yıldırım, H.K.; Altindişli, A. Evaluation of methods for DNA extraction from must and wine. J. Inst. Brew. 2014, 120, 238-243. [CrossRef]

10. Siret, R.; Boursiquot, J.M.; Merle, M.H.; Cabanis, J.C.; This, P. Toward the authentication of varietal wines by the analysis of grape (Vitis vinifera L.) residual DNA in must and wine using microsatellite markers. J. Agric. Food Chem. 2000, 48, 5035-5040. [CrossRef]

11. García-Beneytez, E.; Moreno-Arribas, M.V.; Borrego, J.; Polo, M.C.; Ibáñez, J. Application of a DNA Analysis Method for the Cultivar Identification of Grape Musts and Experimental and Commercial Wines ofVitis viniferaL. Using Microsatellite Markers. J. Agric. Food Chem. 2002, 50, 6090-6096. [CrossRef] [PubMed]

12. Agrimonti, C.; Marmiroli, N. PCR analysis of experimental and commercial wines by means of nuclear and chloroplast SSRs. Eur. Food Res. Technol. 2018, 244, 2127-2140. [CrossRef]

13. Siret, R.; Gigaud, O.; Rosec, J.P.; This, P. Analysis of GrapeVitis viniferaL. DNA in Must Mixtures and Experimental Mixed Wines Using Microsatellite Markers. J. Agric. Food Chem. 2002, 50, 3822-3827. [CrossRef]

14. Recupero, M.; Garino, C.; De Paolis, A.; Cereti, E.; Coisson, J.-D.; Travaglia, F.; Arlorio, M. A Method to Check and Discover Adulteration of Nebbiolo-Based Monovarietal Musts: Detection of Barbera and Dolcetto cv via SSR Analysis Coupled with Lab-On-Chip ${ }^{\circledR}$ Microcapillary Electrophoresis. Food Anal. Methods 2013, 6, 952-962. [CrossRef]

15. Scali, M.; Elisa, P.; Jacopo, B.; Mauro, C.; Vignani, R. Vineyards genetic monitoring and Vernaccia di San Gimignano wine molecular fingerprinting. Adv. Biosci. Biotechnol. 2014, 5, 142-154. [CrossRef]

16. Di Rienzo, V.; Miazzi, M.M.; Fanelli, V.; Savino, V.; Pollastro, S.; Colucci, F.; Miccolupo, A.; Blanco, A.; Pasqualone, A.; Montemurro, C. An enhanced analytical procedure to discover table grape DNA adulteration in industrial musts. Food Control. 2016, 60, 124-130. [CrossRef]

17. Hârţa, M.; Pamfil, D.C.; Pop, R.; Vicaş, S.I. DNA fingerprinting used for testing some Romanian wine varieties. Bulletin UASVM Horticulture 2011, 68, 143-148.

18. Gheţea, L.G.; Motoc, R.M.; Popescu, C.F.; Barbacar, N.; Iancu, D.; Constantinescu, C.; Barbarii, L.E. Genetic profiling of nine grapevine cultivars from Romania, based on SSR markers. Rom. Biotechnol. Lett. 2010, 15, 116-124.

19. Dokupilová, I.; Šturdík, E.; Mihalik, D. Characterization of vine varieties by SSR markers. Acta Chim. Slovaca 2013, 6, 227-234. [CrossRef]

20. Hârta, M.; Pamfil, D. Molecular Characterisation of Romanian Grapevine Cultivars Using Nuclear Microsatellite Markers. Bulletin of University of Agricultural Sciences and Veterinary Medicine Cluj-Napoca. Horticulture 2013, 70, 131-136.

21. Arroyo-García, R.; Ruiz-García, L.; Bolling, L.; Ocete, R.; López, M.A.; Arnold, C.; Ergul, A.; Söylemezo, L.G.; Uzun, H.I.; Cabello, F.; et al. Multiple origins of cultivated grapevine (Vitis vinifera L. ssp. sativa) based on chloroplast DNA polymorphisms. Mol. Ecol. 2006, 15, 3707-3714. [CrossRef]

22. Péros, J.-P.; Berger, G.; Portemont, A.; Boursiquot, J.-M.; Lacombe, T. Genetic variation and biogeography of the disjunct Vitis subg. Vitis (Vitaceae). J. Biogeogr. 2011, 38, 471-486. [CrossRef]

23. Aversano, R.; Basile, B.; Buonincontri, M.P.; Carucci, F.; Carputo, M.; Frusciante, L.; Di Pasquale, G. Dating the beginning of the Roman viticultural model in the Western Mediterranean: The case study of Chianti (Central Italy). PLoS ONE 2017, 12, e0186298. [CrossRef] [PubMed]

24. Baleiras-Couto, M.; Eiras-Dias, J. Detection and identification of grape varieties in must and wine using nuclear and chloroplast microsatellite markers. Anal. Chim. Acta 2006, 563, 283-291. [CrossRef]

25. Boccacci, P.; Akkak, A.; Marinoni, D.T.; Gerbi, V.; Schneider, A. Genetic traceability of Asti Spumante and Moscato d'Asti musts and wines using nuclear and chloroplast microsatellite markers. Eur. Food Res. Technol. 2012, 235, 439-446. [CrossRef] 
26. Pereira, L.; Martins-Lopes, P.; Batista, C.; Zanol, G.C.; Clímaco, P.; Brazão, J.; Eiras-Dias, J.E.; Guedes-Pinto, H. Molecular Markers for Assessing Must Varietal Origin. Food Anal. Methods 2012, 5, 1252-1259. [CrossRef]

27. Lijavetzky, D.; Cabezas, J.A.; Ibáñez, A.; Rodríguez, V.; Martínez-Zapater, J.M. High throughput SNP discovery and genotyping in grapevine (Vitis vinifera L.) by combining a re-sequencing approach and SNPlex technology. BMC Genom. 2007, 8, 424. [CrossRef] [PubMed]

28. A Cabezas, J.; Ibáñez, J.; Lijavetzky, D.; Vélez, D.; Bravo, G.; Rodríguez, V.; Carreño, I.; Jermakow, A.M.; Carreño, J.; Ruiz-García, L.; et al. A 48 SNP set for grapevine cultivar identification. BMC Plant Biol. 2011, 11, 153. [CrossRef] [PubMed]

29. Pereira, L.; Martins-Lopes, P. Vitis vinifera L. Single-Nucleotide Polymorphism Detection with High-Resolution Melting Analysis Based on the UDP-Glucose:Flavonoid 3-O-Glucosyltransferase Gene. J. Agric. Food Chem. 2015, 63, 9165-9174. [CrossRef] [PubMed]

30. Pereira, L.; Gomes, S.; Castro, C.; Eiras-Dias, J.E.; Brazão, J.; Graça, A.; Fernandes, J.R.; Martins-Lopes, P. High Resolution Melting (HRM) applied to wine authenticity. Food Chem. 2017, 216, 80-86. [CrossRef] [PubMed]

31. Gomes, S.; Castro, C.; Barrias, S.; Pereira, L.; Jorge, P.; Fernandes, J.R.; Martins-Lopes, P. Alternative SNP detection platforms, HRM and biosensors, for varietal identification in Vitis vinifera L. using F3H and LDOX genes. Sci. Rep. 2018, 8, 5850. [CrossRef] [PubMed]

32. Del Campo, E.M.; Hoyo, A.D.; Casano, L.M.; Martínez-Alberola, F.; Barreno, E. A rapid and cost-efficient DMSO-based method for isolating DNA from cultured lichen photobionts. Taxon 2010, 59, 588-591. [CrossRef] 